\title{
A Study on Structural Relationships Between Consulting Service Quality, Management Human Capital, and Entrepreneurship
}

\author{
Tae-Young $\mathrm{Kim}^{1} \&$ Yen-Yoo You ${ }^{1}$ \\ ${ }^{1}$ Dept. of Knowledge Service \& Consulting, Hansung University, Seoul, South Korea \\ Correspondence: Tae-Young Kim, Ph.D. Student, Dept. of Knowledge Service \& Consulting, Hansung University, \\ Seoul, South Korea. Tel: 82-10-3651-0741. E-mail: polyolkim@naver.com
}

Received: April 9, 2020

Accepted: May 9, 2020

Online Published: May 23, 2020

doi:10.5430/rwe.v11n2p144

URL: https://doi.org/10.5430/rwe.v11n2p144

\begin{abstract}
Background/Objectives: The purpose of this study is to empirically verify the effect of consulting services quality on management human capital and ultimately Entrepreneurship in the rapidly changing business environment. This study attempted to empirically examine the effect of the consulting service quality perceived by corporate managers on the Business Management Human Capital and Entrepreneurship of the company when the company experienced consulting.

Methods/Statistical analysis: This study conducted survey research on managers $n=255$ in Korea. In this study, we used SPSS 22.0 Version Program to verify the research hypothesis. Next, we performed SEM using the AMOS 22.0 Version program to implement the Structural Equation Modeling. Specifically, Frequency Analysis, Descriptive Analysis, Pearson`s Correlation Analysis, Confirmatory Factor Analysis, Reliability Test, and Pathway Analysis were conducted.

Findings: The major findings are as follows. Process- Quality was found to have a statistically significant effect on Development Ability, Leadership Ability, and Marketing Ability. Next, the Technical-Quality was found to have a statistically significant effect on Development Ability, Recruiting Ability, Leadership Ability, and Marketing Ability. Lastly, only two variables, Leadership Ability and Marketing Ability, which affect Entrepreneurship, were statistically significant. Based on this, we tried to empirically verify the importance of consulting. The results presented in this study have practical implications for empirically verifying the necessity of consulting. According to the research results, it is necessary to make efforts to improve leadership and marketing ability in order to enhance Entrepreneurship.

Improvements/Applications: However, this study has some limitations. Because this study is based on a limited sample, there are some limitations to the generalization of the results. Therefore, if further research is conducted later, we expect that the study will be conducted on more samples.
\end{abstract}

Keywords: consulting service process quality, consulting service technical quality, entrepreneurship, business management human capital, leadership ability, marketing ability

\section{Introduction}

Businesses today are putting more effort into running their businesses than ever before to adapt to changing market conditions. Considering this environment, we can say that the role of consulting to help us understand the current position and strengths and weaknesses of the company more objectively than it is today. The purpose of this study was to explore the empirical effect of the quality of consulting services in the management human capital, which is the value of the core capital of a company. Furthermore, the entrepreneurship, which can be said to be a key factor in corporate innovation. I tried to explore the structural relationship up to.

\section{Related Works}

\subsection{Management Consulting and Consulting Quality}

Consulting goes through the process of initiating, diagnosing, developing, implementing, and terminating management issues with the aim of solving management problems, seeking and exploiting new opportunities, and increasing learning and driving change. Steele (Steele, 1975) defined consulting from a functional point of view as a 
consultant who was not responsible for the task's implementation, assisting in the content and structure of the task in accordance with the consulting process. After signing the agreement, we defined consulting in terms of professional services as a service that diagnoses the management situation from the independent and objective position, suggests solutions, and provides them when help is requested for implementation (Kubr, 2002).

The International Council of Management Consulting Institutes (ICMCI) make the best use of the consultants' knowledge, skills and assets to provide customers with objective advice and professional services to solve problems, create and improve value for their organizations. It is said to help improve performance in terms of growth and growth.

In Williams \& Woodward's (1994) preceding study, consulting is the process by which internal or external consultants provide services to clients (organizations, individuals, internal departments, etc.) to meet their needs. In the definition of Kubr (2002), consulting is also used to solve management and business problems, thereby discovering new opportunities, exploiting them, broadening learning opportunities and implementing change to help achieve the goals of management and organization. Defined as Professional Adviser Service. Simon \& Kumar (Becker, 2009) argued that the achievement of agreed goals, customer satisfaction, timeliness of service delivery, implementation of recommendations and deriving measurable financial performance were factors of consulting quality.

\subsection{Review of Human Capital}

Human Capital Theory argues that individual skills, knowledge, and competences are important sources and valuable resources for economic productivity and that these skills can be built through education and experience (Noe et al., 2015). Becker (Noe et al., 2015) proposes the theory of human capital by dividing it into 'corporate' human capital and 'general' human capital.

General human capital refers to human capital that can be utilized in all industries, not human capital required by a specific company or required by a specific job. Firm-specific human capital refers to human capital embodied in the knowledge and skills required by a firm. It is no surprise that performance is superior to organizations without high levels of human capital.

Since human capital theory has been expanded from economics to other academic fields, there have been many studies on how human capital affects corporate performance. On the relationship human capital and organizational performance, Noe (Drucker, 1985) proposed an integrated model that human capital accumulated through human resource management affects organizational performance.

\subsection{Review of Entrepreneurship}

Research on entrepreneurship began 30 years ago and there are many studies on the definition of entrepreneurship from different perspectives (Gartner, 1988; Kuratko, 2016). There are many studies that define entrepreneurship as a processing activity or psychological feature (Lumpkin and Dess, 1996). Recently, as the number of start-ups has increased, attempts made to examine the relationship between entrepreneurship and the performance of start-ups. Lumpkin \& Dess (Miller, 1983) presented competitive aggression and autonomy as attributes of entrepreneurship, Miller (Morris and Lewis, 1995) also showed innovation, enterprising, risk-taking, and Morris \& Lewis (Schumpeter, 1942) showed innovation, enterprising, adventurous way of thinking and behavior is presented as a construct. Many studies have suggested factors related to motivation such as competitive aggression, autonomy, and desire for achievement (Miller, 1983).

The concept of entrepreneurship has begun to attract attention in earnest from the study of Schumpeter (Schumpeter, 1951), which is the beginning of entrepreneurship research. Schumpeter defined entrepreneurship as a continuous, creative and innovative action that promotes social change. In another study, entrepreneurs call entrepreneurs the driving force in economic development, and entrepreneurship is an innovative act of entrepreneurs to respond creatively to changes in the market environment (Cole, 1959).

Then Cole (1959) expanded the scope of entrepreneurship by observing entrepreneurship decision making or entrepreneur behavior through the flow of information and ideas, and examining the concept of entrepreneurship in three ways: management, innovation, and coordination of external conditions. In Miller (Morris and Lewis, 1995), entrepreneurship is defined as the pursuit of corporate product and market innovation and the overwhelming of competitors by taking some risk and taking a proactive approach.

\section{Proposed Method}

[Hypothesis] to verify in this study is as follows. 
[H1] Process Quality will affect Development Ability.

[H2] Process Quality will affect Recruiting Ability.

[H3] Process Quality will affect Leadership Ability.

[H4] Process Quality will affect Marketing Ability.

[H5] Technical Quality will affect Development Ability.

[H6] Technical Quality will affect Recruiting Ability.

[H7] Technical Quality will affect Leadership Ability.

[H8] Technical Quality will affect Marketing Ability.

[H9] Development Ability will affect Entrepreneurship.

[H10] Recruiting Ability will affect Entrepreneurship.

[H11] Leadership Ability will affect Entrepreneurship.

[H12] Marketing Ability will affect Entrepreneurship.

This study conducted Survey Research, the most widely used in quantitative research, to empirically verify the Research Hypothesis. Survey Research was conducted through Online Survey Research, and an online survey was conducted on South Korean KOREA males and females in their 20s and 50s for 3 days from November 18-20, 2019. As a result, a total of 262 respondents participated. Among them, $\mathrm{N}=255$ was used to conduct statistical analysis, except for the seven parts that did not respond unfaithfully (Sule, 2019); (Tang and Khan, 2018).

In this study, we used IBM's SPSS 22.0 Version Program to verify the research hypothesis. Next, we performed Structural Equation Modeling (SEM) using the AMOS 22.0 Version program to implement the Structural Equation Modeling (SEM). Specifically, Frequency Analysis, Descriptive Analysis, Pearson 's Correlation Analysis, Confirmatory Factor Analysis, Reliability Test (Cronbach 's Alpha), and Pathway Analysis were conducted.

\section{Experimental Results}

\subsection{Demographics Composition}

The demographics composition of the participants in the survey was as follows. First, $\mathrm{N}=255$ people participated, and Gender had 127 males (56.0\%) and 98 females (44.0\%). In terms of age, 45 in 20s (17.6\%), 122 in 30s (47.8\%), 72 in $40 \mathrm{~s}(28.2 \%)$, and $15(5.9 \%)$ were in their 50s or older. The highest percentage of respondents was found. At the education level, less than 1 high school graduate (0.4\%), 13 high school graduates $(5.1 \%), 21$ college graduates $(8.2 \%), 159$ university graduates $(62.4 \%)$, and 61 or more graduate students (23.9) The education level of the survey participants was relatively high.

\subsection{Descriptive and Correlations Analysis}

Next, descriptive analysis was performed to obtain the values of Mean, Standard Deviation, etc. of the main measurement variables. Also, Pearson's Correlations Analysis was conducted to examine the correlations of variables as shown in Table 1. First, in terms of consulting quality, Process Quality $(M=3.769)$ was higher than Technical Quality ( $M=3.557)$. In terms of human capital, Leadership ability $(M=3.847)$ was the highest, followed by Marketing ability $(M=3.758)$, Development ability $(M=3.482)$, and Recruiting ability $(M=2.844)$. Mean was low.

In the case of correlation, development ability and management consulting quality factors, Progress Quality and Development ability $(r=.348, p<.01)$, and Technical Quality and Development ability $(r=.248, p<.01)$ were all statistically significant. It had a positive correlation. In relation to the recruiting ability, both Progress Quality and Recruiting ability $(\mathrm{r}=.390, p<.01)$, and Technical Quality and Recruiting ability $(\mathrm{r}=.533, p<.01)$ showed statistically significant positive correlations. In terms of leadership ability, both Progress Quality and Leadership ability $(\mathrm{r}=.524, p<.01)$, and Technical ability and Leadership ability $(\mathrm{r}=.662, p<.01)$ showed statistically significant positive correlations. There was a relatively large correlation. In terms of marketing ability, Progress Quality and Marketing ability $(\mathrm{r}=.597, p<.01)$, and Technical Quality and Marketing ability $(\mathrm{r}=.532, p<.01)$ showed statistically significant positive correlations.

Finally, for the correlation between Entrepreneurship and Human capital, Entrepreneurship and Development ability $(\mathrm{r}=.300, p<.01)$, Entrepreneurship and Recruiting ability $(\mathrm{r}=.447, p<.01)$, Entrepreneurship and Leadership ability $(\mathrm{r}=.608, p<.01)$, Entrepreneurship and Marketing ability $(\mathrm{r}=.564, p<.01)$ all showed statistically significant positive correlation. Among them, the correlation between leadership ability and Entrepreneurship was the highest. 
Table 1. Descriptive and correlations analysis

\begin{tabular}{|c|c|c|c|c|c|c|c|c|}
\hline & 1 & 2 & 3 & 4 & 5 & 6 & 7 & $\mathbf{M}(\mathbf{S D})$ \\
\hline Process Quality & 1 & $.526 * *$ & $.348 * *$ & $.390 * *$ & $.524 * *$ & $.597 * *$ & $.523 * *$ & $3.769(.855)$ \\
\hline Technical Quality & $.526^{* *}$ & 1 & $.248 * *$ & $.533 * *$ & $.662 * *$ & $.532 * *$ & $.635 * *$ & $3.557(.937)$ \\
\hline $\begin{array}{c}\text { Development } \\
\text { Ability }\end{array}$ & $.348 * *$ & $.248^{* *}$ & 1 & $.304 * *$ & $.250 * *$ & $.281 * *$ & $.300 * *$ & $3.482(.938)$ \\
\hline $\begin{array}{c}\text { Recruiting } \\
\text { Ability }\end{array}$ & $.390 * *$ & $.533 * *$ & $.304 * *$ & 1 & $.472 * *$ & $.531 * *$ & $.447 * *$ & $2.844(.936)$ \\
\hline $\begin{array}{l}\text { Leadership } \\
\text { Ability }\end{array}$ & $.524 * *$ & $.662 * *$ & $.250 * *$ & $.472 * *$ & 1 & $.507 * *$ & $.608 * *$ & $3.847(.995)$ \\
\hline $\begin{array}{c}\text { Marketing } \\
\text { Ability }\end{array}$ & $.597 * *$ & $.532 * *$ & $.281 * *$ & $.531 * *$ & $.507 * *$ & 1 & $.564 * *$ & $3.758(.793)$ \\
\hline Entrepreneurship & $.523 * *$ & $.635^{* *}$ & $.300 * *$ & $.447 * *$ & $.608 * *$ & $.564 * *$ & 1 & $3.909(.773)$ \\
\hline
\end{tabular}

\subsection{The Results of Confirmatory Factor Analysis}

In this study, Confirmatory Factor Analysis and Cronbach's alpha score were calculated to verify the Validity and Reliability of Scale before the [Test Hypothesis]. The detailed results are described in as shown in Table 2. First of all, the model fit-of-goodness of Confirmatory Factor Analysis showed that the Chi-square score was statistically significant. In addition, the Structural Equation Modeling should also refer to the Multiple Index other than the Chi-square score. Therefore, the indexes of RMR, NFI, TLI, CFI, and RMSEA were examined. In general, RMR is less than .80, NFI is greater than .80, TLI and CFI are greater than .90, and RMSEA is less than 1.00. The measurement items in this study met all the relevant criteria and showed no problem invalidity. In addition, as a result of the calculation of the Cronbach's alpha coefficient for reliability verification, the reliability showed more than .60, indicating that there was no problem in reliability. Therefore, Validity and Reliability were secured.

Table 2. Model-fit of confirmatory factor analysis model

\begin{tabular}{ccccccc}
\hline$\chi^{2}$ & $d f$ & RMR & NFI & TLI & CFI & RMSEA \\
\hline $406.009^{* * *}$ & 250 & .054 & .894 & .947 & .956 & .050 \\
\hline
\end{tabular}

$* p<.05, * * p<.01, * * * p<.001$

In general, if the standardized factor loading in Structural Equation Modeling is over .700, it is a very good level and must meet the criteria of over .500. It also states that the score for Critical Ration must be 1.96 or higher. As shown in the results of Table 3, we verified that all items met the criteria.

Table 3. Factor loading of confirmatory factor analysis

\begin{tabular}{llllll}
\hline \multirow{2}{*}{ Variables } & \multicolumn{1}{c}{ Items } & $\begin{array}{c}\text { Standardized } \\
(\boldsymbol{\beta})\end{array}$ & Estimate & S.E. & C.R. \\
\hline \multirow{3}{*}{$\begin{array}{l}\text { Process Quality } \\
\text { The task selected during the consulting } \\
\text { process was appropriate. }\end{array}$} & 0.812 & 1.000 & & \\
\cline { 2 - 7 } & $\begin{array}{l}\text { The guidance period was appropriate in } \\
\text { carrying out the consulting. }\end{array}$ & 0.851 & 0.995 & 0.069 & $14.397^{* * * *}$ \\
\cline { 2 - 6 } & Consulting went fast. & 0.790 & 0.849 & 0.063 & $13.368^{* * *}$ \\
\hline
\end{tabular}




\begin{tabular}{|c|c|c|c|c|c|}
\hline \multirow{4}{*}{$\begin{array}{l}\text { Technical } \\
\text { Quality }\end{array}$} & $\begin{array}{l}\text { Achieved the goals set during the } \\
\text { consulting plan. }\end{array}$ & 0.862 & 1.000 & & \\
\hline & $\begin{array}{l}\text { Achievement compared to consulting } \\
\text { input cost. }\end{array}$ & 0.868 & 1.051 & 0.061 & $17.279 * * *$ \\
\hline & $\begin{array}{l}\text { The improvements and alternatives } \\
\text { presented in the consulting results were } \\
\text { satisfactory. }\end{array}$ & 0.718 & 0.806 & 0.062 & $12.970 * * *$ \\
\hline & $\begin{array}{l}\text { After the consulting was over, the } \\
\text { aftercare was satisfactory. }\end{array}$ & 0.781 & 0.841 & 0.057 & $14.737 * * *$ \\
\hline \multirow{2}{*}{$\begin{array}{l}\text { Development } \\
\text { Ability }\end{array}$} & $\begin{array}{l}\text { Our company has enough ability to } \\
\text { develop new products. }\end{array}$ & 0.744 & 1.000 & & \\
\hline & $\begin{array}{l}\text { We have a company that can make } \\
\text { technical cooperation in developing new } \\
\text { products. }\end{array}$ & 0.712 & 0.861 & 0.097 & $8.878 * * *$ \\
\hline \multirow{3}{*}{$\begin{array}{l}\text { Recruiting } \\
\text { Ability }\end{array}$} & $\begin{array}{l}\text { Our company produces and implements a } \\
\text { recruitment planning manual to secure } \\
\text { talent. }\end{array}$ & 0.581 & 1.000 & & \\
\hline & $\begin{array}{l}\text { Our company rewards more than any } \\
\text { other industry. }\end{array}$ & 0.654 & 1.152 & 0.154 & $7.504 * * *$ \\
\hline & $\begin{array}{l}\text { Our company regularly trains its members } \\
\text { to acquire new skills and knowledge. }\end{array}$ & 0.771 & 1.399 & 0.173 & $8.108 * * *$ \\
\hline \multirow{3}{*}{$\begin{array}{l}\text { Leadership } \\
\text { Ability }\end{array}$} & Our company motivates its members. & 0.893 & 1.000 & & \\
\hline & $\begin{array}{l}\text { Our company tries to reflect and improve } \\
\text { the recommendations of our members. }\end{array}$ & 0.893 & 1.070 & 0.054 & $19.669 * * *$ \\
\hline & $\begin{array}{l}\text { Our company has the capacity to manage } \\
\text { organizational resources and its members. }\end{array}$ & 0.788 & 0.899 & 0.057 & $15.901 * * *$ \\
\hline \multirow{3}{*}{$\begin{array}{l}\text { Marketing } \\
\text { Ability }\end{array}$} & $\begin{array}{l}\text { Our company manages customers to build } \\
\text { relationships with major customers. }\end{array}$ & 0.610 & 1.000 & & \\
\hline & $\begin{array}{l}\text { Our company tries to maintain a corporate } \\
\text { image and brand image. }\end{array}$ & 0.643 & 0.953 & 0.118 & $8.076^{* * *}$ \\
\hline & $\begin{array}{l}\text { We know exactly what's going on in our } \\
\text { products, consumers, and markets. }\end{array}$ & 0.717 & 1.015 & 0.117 & $8.705^{* * * *}$ \\
\hline \multirow{7}{*}{ Entrepreneurship } & $\begin{array}{l}\text { Our company tends to undertake } \\
\text { innovative projects to develop what our } \\
\text { customers want. }\end{array}$ & 0.699 & 1.000 & & \\
\hline & $\begin{array}{l}\text { Our company values creative ideas even } \\
\text { when risks exist. }\end{array}$ & 0.776 & 1.138 & 0.103 & $11.017 * * *$ \\
\hline & $\begin{array}{l}\text { We always try to be a market leader by } \\
\text { introducing new products and services. }\end{array}$ & 0.718 & 1.045 & 0.102 & $10.256^{* * *}$ \\
\hline & $\begin{array}{l}\text { Our company is proactive in dealing with } \\
\text { uncertain situations. }\end{array}$ & 0.798 & 1.107 & 0.097 & $11.422 * * *$ \\
\hline & $\begin{array}{l}\text { Our company has a strong tendency to } \\
\text { take a competitive stance to increase the } \\
\text { company's value with competitors. }\end{array}$ & 0.611 & 0.945 & 0.106 & $8.945^{* * *}$ \\
\hline & $\begin{array}{l}\text { Our company tends to pursue growth } \\
\text { rather than management stability. }\end{array}$ & 0.597 & 0.872 & 0.100 & $8.739 * * *$ \\
\hline & We strive to explore creative ideas. & 0.990 & 1.599 & 0.165 & $9.691 * * *$ \\
\hline
\end{tabular}

$* p<.05, * * p<.01, * * * p<.001$ 


\subsection{The Results of Pathway Analysis}

Next, to verify empirically the research hypotheses [H1] to [H12], a Pathway Analysis was conducted once. First, the Model-Fit of Pathway Analysis showed statistically significant Chi-square score and met all criteria of RMR, NFI, TLI, CFI, and RMSEA as shown in Table 4.

Table 4. Model-fit of pathway analysis model

\begin{tabular}{ccccccc}
\hline$\chi^{2}$ & $d f$ & RMR & NFI & TLI & CFI & RMSEA \\
\hline $486.062^{* * * *}$ & 259 & .067 & .873 & .925 & .935 & .059 \\
\hline
\end{tabular}

$* p<.05, * * p<.01, * * * p<.001$

The Results of Pathway Analysis are described in detail as shown in Table 5 and the research hypothesis results of this study are described in [Figure 1] below. [H1], [H3], [H4], [H5], [H6], [H7], and [H8]. [H11] was supported (Tanoh and Osei-Assibey, 2019); (Tanoh et al., 2019). On the other hand, [H2], [H9], and [H10] have been rejected. Therefore, to summarize the results of this study, Process Quality was found to have a statistically significant effect on Development Ability, Leadership Ability, and Marketing Ability. Next, the technical quality was found to have a statistically significant effect on Development Ability, Recruiting Ability, Leadership Ability, and Marketing Ability. Lastly, only two variables, Leadership Ability and Marketing Ability, which affect Entrepreneurship, were statistically significant.

The purpose of this study is to empirically verify the effect of consulting services quality on managing human capital and ultimately Entrepreneurship in the rapidly changing business environment. Based on this, this study has practical meaning in empirically revealing the importance of corporate consulting.

Table 5. The results of pathway analysis

\begin{tabular}{|c|c|c|c|c|c|c|c|}
\hline \multicolumn{3}{|c|}{ Pathway } & \multirow{2}{*}{$\begin{array}{c}\begin{array}{c}\text { Standardized } \\
(\boldsymbol{\beta})\end{array} \\
0.221\end{array}$} & \multirow{2}{*}{$\begin{array}{c}\text { Estimate } \\
0.263\end{array}$} & \multirow{2}{*}{$\begin{array}{l}\text { S.E. } \\
0.107\end{array}$} & \multirow{2}{*}{$\frac{\text { C.R. }}{2.461^{*}}$} & \multirow{2}{*}{$\begin{array}{c}p \\
0.014\end{array}$} \\
\hline Process Quality & ( & $\begin{array}{c}\text { Development } \\
\text { Ability }\end{array}$ & & & & & \\
\hline Process Quality & 1 & Recruiting Ability & 0.138 & 0.106 & 0.066 & 1.610 & 0.107 \\
\hline Process Quality & 1 & Leadership Ability & 0.241 & 0.274 & 0.077 & $3.551 * * *$ & $* * *$ \\
\hline Process Quality & 1 & Marketing Ability & 0.507 & 0.413 & 0.067 & $6.151^{* * *}$ & $* * *$ \\
\hline Technical Quality & 1 & $\begin{array}{l}\text { Development } \\
\text { Ability }\end{array}$ & 0.566 & 0.724 & 0.123 & $5.874 * * *$ & $* * *$ \\
\hline Technical Quality & 1 & Recruiting Ability & 0.650 & 0.538 & 0.091 & $5.885^{* * *}$ & $* * *$ \\
\hline Technical Quality & 1 & Leadership Ability & 0.615 & 0.750 & 0.091 & $8.246^{* * *}$ & $* * *$ \\
\hline Technical Quality & 1 & Marketing Ability & 0.467 & 0.408 & 0.071 & $5.770 * * *$ & $* * *$ \\
\hline $\begin{array}{l}\text { Development } \\
\text { Ability }\end{array}$ & 1 & Entrepreneurship & 0.141 & 0.097 & 0.060 & 1.630 & 0.103 \\
\hline Recruiting Ability & 1 & Entrepreneurship & 0.035 & 0.038 & 0.087 & 0.432 & 0.666 \\
\hline Leadership Ability & 1 & Entrepreneurship & 0.296 & 0.214 & 0.058 & $3.679 * * *$ & $* * *$ \\
\hline Marketing Ability & 1 & Entrepreneurship & 0.460 & 0.465 & 0.111 & $4.201 * * *$ & $* * *$ \\
\hline
\end{tabular}

$* p<.05, * * p<.01, * * * p<.001$ 


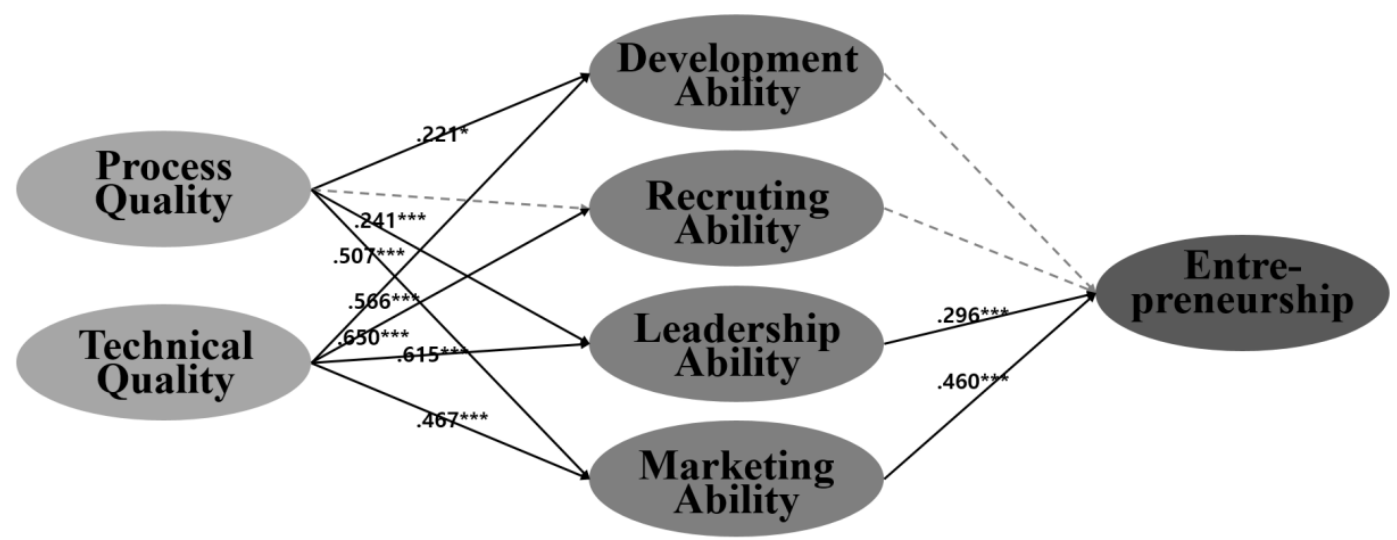

Figure 1. The results of research hypothesis

\section{Conclusion}

The purpose of this study is to structurally explore the relationship between corporate consulting service quality perception and human capital and entrepreneurship. The major findings are as follows. First of all, Process-Quality has been shown to affect development, leadership, and marketing ability. Technical-Quality has been shown to affect development, recruiting, leadership, and marketing ability. Next, the human capital factors that affect entrepreneurship were leadership and marketing ability factors.

According to the research results, it is necessary to make efforts to improve leadership and marketing ability in order to enhance Entrepreneurship. In addition, the theoretical and practical implications of this study exist in that empirically verifying that consulting quality is an important factor affecting Entrepreneurship in that consulting quality has a significant influence on leadership and marketing ability.

However, this study has some limitations. Because this study is based on a limited sample, there are some limitations to the generalization of the results. Therefore, if further research is conducted later, we expect that the study will be conducted on more samples.

\section{Acknowledgment}

This research was financially supported by Hansung University.

\section{References}

Becker, G. S. (2009). Human capital: A theoretical and empirical analysis, with special reference to education. Chicago: University of Chicago Press, pp. 23-44, p. 115.

Cole, A. H. (1959). Business enterprise in its social setting. Harvard University Press, p. 93.

Drucker, P. F. (1985). Entrepreneurial strategies. California Management Review, $27(2), 6$.

Gartner, W. B. (1988). "Who is an entrepreneur?" is the wrong question. American Journal of Small Business, 12(4), 11-32.

Kubr, M. (2002). Management consulting: A guide to the profession. Geneva: International Labour Organization, pp. 6-10.

Kuratko, D. F. (2016). Entrepreneurship: Theory, process, and practice. Mass: Cengage Learning, pp. 101-113.

Lumpkin, G. T., \& Dess, G. G. (1996). Clarifying the entrepreneurial orientation construct and linking it to performance. Academy of Management Review, 21(1), 135-172.

Miller, D. (1983). The correlates of entrepreneurship in three types of firms. Management Science, 19-21.

Morris, M. H., \& Lewis, P. S. (1995). The determinants of entrepreneurial activity. European Journal of Marketing, 48-51.

Noe, R. A., Hollenbeck, J. R., Gerhart, B., \& Wright, P. M. (2015). Human resource management: Gaining a competitive advantage. New York: McGraw-Hill Education, p. 105.

Schumpeter, J. A. (1942). Capitalism, socialism and democracy. NY: Harper and Brothers, pp. 35-37. 
Schumpeter, J. A. (1951). Economic theory and entrepreneurial history, R.V. Clemence, (Ed.), pp. 44-48.

Simon, A., \& Kumar, V. (2001). Clients' views on strategic capabilities which lead to management consulting success. Management Decision, 39(5), 362-372.

Steele, F. (1975). Consulting for organizational change. Mass: University of Massachusetts Press, 18-25.

Sule, B. (2019). The 2019 general election in Gombe State: An analysis of the voting pattern, issues, impacts and its implications. International Journal of Social Sciences Perspectives, 4(2), 62-75. https://doi.org/10.33094/7.2017.2019.42.62.75

Tang, Y., \& Khan, M. B. U. (2018). Internal law enforcement challenges in Bangladesh: An Analysis. Humanities and Social Sciences Letters, 6(3), 106-120.

Tanoh, D., \& Osei-Assibey, E. (2019). Migration as a livelihood strategy: The case of internal migration in Ghana. Journal of Social Economics Research, 6(1), 50-60.

Tanoh, D., Boadu, S., \& Obeng, E. (2019). An empirical assessment of the impact of access to credit on farm output: A case study of Sefwi-Wiawso Municipality Ghana. Journal of Social Economics Research, 6(1), 20-33.

Williams, A. P., \& Woodward, S. (1994). Consultancy roles: In the competitive consultant. London: Palgrave Macmillan, pp. 28-36. 